Theories \& Applications, the International Edition

Printed Version: (ISSN 2090-5262)

Online Version: (ISSN 2090-5270)

July 2013, Volume 3, No. 2 Pages (51 - 58)

\title{
Career Pressure and Its Relation With Educational Performance for Physical Education Teachers After $25^{\text {th }}$ January Revolution
}

\author{
Abo Alnaga Ahmed Az Alden*, Noor Taha Ebrahim Hussein**
}

\section{Introduction and Research Problem}

$\mathrm{M}$ odern age is called the time of science and technology progress and it is called also the period of psychological pressures and the age of anxiety and tension. Because of the technological, social and economic speed change and because of complex life styles. As a result of that there are a lot of competition between individuals to cope with this change and development. Consequently the responsibility increases to the individual who works hard to achieve a standard which is suitable for their ambition and hope.

Every person suffers from these pressures but not the same like each other according to the person himself , the place where he lives and the job which he does the teaching career generally and especially a physical education is one of the career which has several pressures arouses inside and outside school which negatively affects the performance standard of the teacher . Saving the suitable educational environment for the physical education teacher to perform his work efficiently to achieve the physical education goals $(5: 12)$.

The career pressure phenomena attracts the attention of many researchers in some jobs and one of these jobs physical education teaching. It is a career which has several pressures situations on physical education teacher and this leads to decrease his performance standard and it is finally leads to his job leaving and his retirement or he faces the pressures and adapt with it(2:12).

\footnotetext{
* Professor at the College of Physical Education, Mansoura University, Egypt.

* Lecturer, Department of Curriculum and Instruction, College of Physical Education, Mansoura University, Egypt.

career pressure phenomena is one of the career phenomenon and it is the most important one
}

because it affects the standard of teacher, school and society. So it is the age phenomena in developed and developing countries and no one is empty of it (10:2).

Results study of Hasers and Nasser(2002) refers that the teacher work usually has several problems, obstacles and career duties which may increase the pressure.

The pressures of teaching are pupils behaviormuch duty of work - less courage from partners and administration written work which has no relation with teaching (27:67).

Khedr Mekhemar Abo zeed results ( 2002) refer that teaching pressure is one bad psychology of teacher $(5: 281$.)

Susanne Carter ( 1994) refers that what is the teacher lost because of psychological pressure in his work as follows losing energy - losing enthusiasm - losing career satisfaction - losing concentration - losing encouragement - losing interest - losing fun- losing confidence - losing enjoyment - losing joy of teaching(25:14).

Shama Mohamed Khalifa Al Khalifa (1999) refers that the career pressure for the teacher is the school situations which is the source of pressure and it contain more work and the struggle, ambiguous of work which cause tension or pressure for long to the teacher when he tries to achieve his work requests and he may feel upset because he can't achieve task goals(6:7).

Physical education teacher considers the most one who exposed to this tension and there are a lot of factors which leads to this pressure as asking him to do some duties which aren't from his work, asking him to teach some lessons which are not in his timetable, he doesn't satisfy on his monthly salary, his weak economic condition, there are a lot of pupils in the classes, 
bad relation with school and other partners and weak chances to promote which leads to less motivation and creation in work and that means teachers can't adapt There are some teachers who can face these risks, threats and pressure and adapt with them. There are others who fail to adapt and exposed to healthy and psychological problems which leads to nervous breakdown and decrease performance standard (11:89).

After 25th January revolution ministry of education has published some decisions in September 2011 with a title ( Facts about the government efforts in the last sixth months to improve teachers condition and educational process) This because the ministry appreciates teacher's role. The government communicated with the teachers to raise their standard and achieve what they hope. The most important decisions in this subject for the sake of teachers are :

- Promotion to the higher jobs according to professional failure.

- 130000 new teachers promotion to a higher rank in the job

- Increase of over salary money to \%200 form the essential salary.

- Increase of young teachers ( with contracts) with the percentage of $\% 75$.

- Increase of the teacher salary \%50 and other teachers \%25 ( first teacher, first teacher A, expert teacher and older teacher.

-Employ the teachers of lectures or who works by a prize system.

- Directors choice depends on their efficiency not on their age ( the beginning in the experimental schools) and give them more money(1200 : 2000 pounds) according to the stage to encourage them.

- Giving more financial and administrative authorities to the fathers party.

- Reorganize the total educational evaluation system in primary and preparatory schools.

1. physical activity in primary school is compulsory.

physical activity in preparatory school is compulsory.
2. increase of educational buildings (\%150) compared with last year and this decrease the number of pupils in schools and give the chance to employ new teachers

- Double the money of technology development so it becomes 410 million pounds in addition offer 600 million pounds to educational projects and this enables schools to use electronic board.

- Increase the balance of technical education.

- Let the simple disabled pupils to join ordinary schools.

- Starting in establish excellent pupils in science and technology

The researcher tried to know the reasons for career pressure which may affect physical education teachers before and after 25th January Revolution and its relation with teaching performance and how much the decisions which came in the government paper to take part in improving teachers conditions to relieve this career pressure and subsequently raise the standard of education performance(16).

\section{The Importance of the Research}

The importance of this research comes from it is an attempt to know that :

1. The relation between career pressure and education performance to physical education teachers.

2. Supporting physical education teachers situation to face career pressure.

3. An attempt to know career pressure before and after 25th January Revolution.

\section{Research Goals}

Knowing the career pressure and its relation with education performance to physical education teachers before and after 25th January Revolution through :

1. Knowing the reasons for career pressure to physical education teachers before and after 25th January Revolution. 
2. Knowing the difference between male and female teachers in career pressure before and after 25th January Revolution.

3. The relation between career pressure and education performance to physical education teachers before and after 25th January Revolution.

\section{$\underline{\text { Research Assumptions }}$}

1. There are different reasons for career pressure to physical education teachers before and after 25th January Revolution.

2. There are differences have statistics meaning in career pressure between male and female teachers before and after 25th January Revolution.

3. There are differences have statistics meaning between career pressure and education performance to physical education teachers before and after 25th January Revolution.

\section{Curriculum Research}

The researcher use the descriptive curriculum with survey form because it is suitable for the nature of the research.

\section{Research sample and society:}

Society of the research is male and female physical teachers who gain Bachelor of Physical Education and work in education field in Gharbia Governorate in 2011-2012 school year and they are (150) teachers. The sample of research is chosen haphazardly and it is (50) male and female physical teachers.

\section{Tools of gathering data:}

- The measure of career pressure to physical education teachers to know the reasons and factors which lead to pressures of physical education teachers and it consists of (51) phrases formed in 4 groups and the researcher does that herself

- Form of education performance to physical education teachers and it consists of (53) phrases formed in 4 groups and the researcher does that herself

Steps of education performance form design
Through theorical reading and referential studies and take opinions of 8 experts in physical education methodology researcher prepared form to measure education performance to physical education teachers this form includes 5 dimensions

They are : personal qualities - form and measure behavioral goals ( physical - skillfully - psychologically - emotionally ) - lesson planning - lesson achieving - evaluation in elementary view

1. Elementary view of the suggested lists is shown to the experts to make sure they are suitable to measure education performance. We reached to 4 dimensions and they are : personal qualities - physical education lesson planning achieving physical education lesson evaluation and measure physical education lesson .

2 . In the light of percent view to the concluded dimensions. We distributed 85 phrases to the experts to make sure they are suitable to measure education performance and the lingual form of them. We reached 75 phrases after experts view. They are included.

3. Analytical elementary is used to reach the least number of concluded factors which represent phrases having high relation and they are supposed to reflect the same characteristics

4. The number of list phrases is 48 phrases. Only 27 phrases were cancelled after analytical elementary.

5. The education performances are shown to some specialist judges in methodology to form final view to these performances.

6. After that we determined the phrases under every dimension.

7. We took the opinion of the judges on the importance of every dimension. they are included.

8. We determined mark to each dimension and determined the full mark according to tripartite measure of Lekert. ( accepted $=3$ marks - don't know $=2$ marks - not accepted $=1$ mark ) we counted the full mark to the list. These are included.

9. We did the scientific treatments to the education performance list by using analytical elementary. These are included. 


\section{Discussion of Results}

And to answer the first supposition

1. The percentages and $\mathrm{K} 2$ to the phrases of career dissatisfactory in career pressure to physical education teachers before and after 25th January Revolution in El Dakahlia Governorate. and the Highest career reasons in the factor career dissatisfactory before 25th January Revolution represent in phrases ( 9 ) ( 5) (6) with the value of $\mathrm{K} 2(62,86)(57,88)$ ( $42,04)$ in order. While the highest career reasons in the factor career dissatisfactory after 25th January Revolution represent in phrases ( 14) (16) (4) with the value of $\mathrm{K} 2$ ( 49,12 ) ( $31,00)(20,92)$ in order. Thus the results reflect the spirit of revolution as they show that the highest pressure reasons before the revolution are related to financial sides then abstract sides. After the revolution the highest reasons represent the abstract sides only because teachers feel freedom and self care as this spirit was killed in the teacher and the Egyptians in general. Mohamed Alarabi Shamoon and Amr Mohamed Abd Elrazek ( 2003) refer that the social pressure is the highest pressure the physical teacher suffer from it and it starts in the family and close friends. This result agrees with Mohamed Hassen Allawy ( 1998) He refers that the financial conditions leads to abstract and physical pressure and they are the most problems which affect teachers.

2. The repetition, percentages and $\mathrm{K} 2$ of the relation between the, teacher, administration and supervision phrases in career pressures to the physical education teachers before and after 25th January revolution in El Dakahlia Governorate the highest career reasons in the factor of teacher's relation with the administration and supervision before 25th January revolution are represent in the phrases ( 12) (10) (7) with the value of $K 2$ ( 36,64 ) ( $33,76)(28,88)$ in order While the highest career reasons in the factor teacher's relation with the administration and supervision after 25th January revolution are represent in the phrases (15) ( 7 ) (9) ( 10) with the value of K2 $(36,64)$ $(30,28)(18,76)$ in order. It is shown from the result agreement in most of reasons before and after revolution. The explanation of that most decisions which were recommended be the government weren't achieved completely and there are still mistakes in the administration, financial and technical aspects. This agrees with Omar Ahmed Badran study which said that disability in making friendly relation between teachers and supervisors leads to career and psychological pressure. This agrees with Manal Geweda Abo Elmagd study (2005) and Amr Hassan Ahmed Badran study ( 2007 ) .

3. The repetition, percentages and $\mathrm{K} 2$ of career pressure phrases to the physical education teachers before and after revolution in Dakahlia governorate the highest career reasons in the career pressure factor before revolution are represent in the phrases (6) (9) (11) with the value of K2 $(33,64)(26,44)(16,00)$ in order. While the highest career reasons in the factor career pressure after the revolution are represent in the phrases ( 1 ) ( 7 ) ( 4 ) (10) with the value of K2 $(18,76)(11,32)(9,16)$ in order . Amr Hassan Ahmed Badran said according to Sabri Ebrahim Omran's view that the most important source of psychological pressures are the pressure of teaching. The more pressure on the teacher the more annoyance he has and this also leads to losing teaching desire. This also agrees with Amr Hassan Ahmed Badran study according to Ezat Abd Elhamid Hassan view that the concept of the teacher satisfactory is the total of attitudes which were formed by the teacher about his work and how much this work satisfy his need from food, clothing, house and daily financial conditions more over the feeling of promotion, safety and good relations with the partners,pupils and school administration. Having appreciation and respect from the others. The work which satisfy these needs doesn't cause career or psychological pressures and if there are pressures then they come from daily life problems. The usual man can't stand these problems.

4. It is shown from the repetition, percentages and K2 of ability phrases to face career pressures to the physical education teachers before and after revolution in Dakahlia governorate highest career reasons in the ability factor to face pressures before revolution are represent in the phrases ( 1 ) ( 5 ) ( 4 ) with the value of $\mathrm{K} 2(33,76)(14,44)(13,42)$ in order. While highest career reasons in the ability factor 
to face pressures after revolution are represent in the phrases ( 1 ) (3) ( 4 ) with the

value of K2 (72,82) $(25,48)(14,56)$ in order.

And to answer the second supposition:
5. The meaning of differences between male and female teachers in career pressure before and after 25th January Revolution in El Gharbia Governorate.

\begin{tabular}{|c|c|c|c|c|c|c|c|}
\hline \multirow{2}{*}{ number } & \multirow{2}{*}{$\begin{array}{l}\text { Dimensions career } \\
\text { pressure measure }\end{array}$} & \multicolumn{2}{|c|}{$\begin{array}{l}\text { Male teacher } \\
\quad(\mathrm{N}=20)\end{array}$} & \multicolumn{2}{|c|}{$\begin{array}{l}\text { Female teacher } \\
(\mathrm{N}=30)\end{array}$} & \multirow[t]{2}{*}{ Value } & \multirow{2}{*}{$\begin{array}{l}\text { Statistics } \\
\text { meaning }\end{array}$} \\
\hline & & $\begin{array}{r}\text { arithmetic } \\
\text { average }\end{array}$ & $\begin{array}{c}\text { standard } \\
\text { deviation }\end{array}$ & $\begin{array}{l}\text { standard } \\
\text { average }\end{array}$ & $\begin{array}{l}\text { arithmetic } \\
\text { deviation }\end{array}$ & & \\
\hline 1 & Career dissatisfaction & 57,46 & 6,74 & 56,58 & 6,68 & 32,0 & Nonfunction \\
\hline 2 & $\begin{array}{c}\text { Relationbetween } \\
\text { teacher, administration } \\
\text { schooland supervision }\end{array}$ & 91,43 & 14,77 & 90,50 & 14,29 & 22,0 & Nonfunction \\
\hline 3 & Career pressure & 49,13 & 7,47 & 47,65 & 7,78 & 66,0 & Nonfunction \\
\hline 4 & $\begin{array}{l}\text { The ability to face } \\
\text { pressure }\end{array}$ & 24,06 & 4,77 & 23,10 & 5,36 & 67,0 & Nonfunction \\
\hline & Total & 222,10 & 27,58 & 218,1 & 26,68 & 51,0 & Nonfunction \\
\hline
\end{tabular}

The valie of $(T)$ in the timetable on the Moaanaweh standard $(50,5)=(1,68)$

$(N=50)$

It is shown from the previous timetable that there are non function differences statistically between male and female teachers in the career pressure before and after 25th January Revolution in El Gharbia Governorate in the dimensions of measuring career pressure which is calculated less than its value in the timetable on Moaanaweh standard ( 50,5)

The relation between career pressure and educational efficiency to physical education teachers before and after 25th January Revolution in El Gharbia Governorate it is shown there are non function differences between male and female teachers in career pressures before and after 25th January revolution in Elgharbia Governorate in measuring the career pressures. The researcher said that it is because there are still a lot of obstacles in front of teachers that leads to career pressures and because some decisions weren't be achieved completely. This result disagrees with the result of Youssef Abd Elfatah ( 1999) Richardson . But the results agrees with Ayman Ali Abd Elhameed Elshaer study ( 1999) Manal Geweda Abo Elmagd ( 2005) Amr Hassan Ahmed Badran study ( 2007 ) . There are no differences between Male and female teachers in the psychological pressure which directly leads to career pressures. As consequence to this result we can't support the second supposition which said that ( There are statistical differences in career pressures between male and female teachers before and after 25th January revolution ) .

And to answer the third supposition:

6. Correlation coefficient between career pressure and teaching Performance to physical education teachers before and after 25th January Revolution in El Gharbia Governorate

\begin{tabular}{|c|c|c|c|}
\hline Number & The changes & \multicolumn{2}{|c|}{ Teaching Performance } \\
\hline \multirow{2}{*}{1} & \multirow{2}{*}{ Career pressure } & $\begin{array}{c}\text { Before25thJanuary } \\
\text { revolution }\end{array}$ & 0.11 \\
\cline { 3 - 4 } & & $\begin{array}{c}\text { After25th January } \\
\text { revolution }\end{array}$ & $0.43^{*}$ \\
\hline
\end{tabular}

*Value (r) Tabulated according to maanaweeh $(0.05)=(37,0)$ *Value $(\boldsymbol{r})$ Tabulated according to maanaweeh $(\mathbf{0 . 0 5})=(\mathbf{3 7}, \mathbf{0})$
Differences indication between male and female after the Revolution (25) January Gharbia teachers in the teaching efficiency before and Governorate 


\begin{tabular}{|c|c|c|c|c|c|c|}
\hline \multirow{3}{*}{$\begin{array}{c}\text { Teaching efficiency } \\
\text { measure }\end{array}$} & \multicolumn{2}{|c|}{ female teachers } & \multicolumn{2}{|c|}{ male teachers } & $\begin{array}{c}\text { value of } \\
(\mathrm{t})\end{array}$ & $\begin{array}{c}\text { Statistical } \\
\text { significance }\end{array}$ \\
\cline { 2 - 5 } & $\begin{array}{c}\text { Standard } \\
\text { deviation }\end{array}$ & $\begin{array}{c}\text { arithmetic } \\
\text { average }\end{array}$ & $\begin{array}{c}\text { Standard } \\
\text { deviation }\end{array}$ & $\begin{array}{c}\text { arithmetic } \\
\text { average }\end{array}$ & \multirow{2}{*}{0,80} & non function \\
\cline { 2 - 5 } & 8,65 & 147,15 & 6,90 & 146,96 & \\
\hline
\end{tabular}

Value (t) Tabulated according to maanaweeh $(0.05)=(1.68)$

There is not statistically significant differences between male and female teachers in the teaching efficiency before and after the Revolution (25) January Gharbia Governorate, where the value of $(t)$ less than the value calculated $(\mathrm{t})$ indexed in the maanaweeh level (0.05)

There is not statistically significant differences between male and female teachers in the teaching efficiency before and after the Revolution (25) January Gharbia Governorate, where the value of $(t)$ less than the value calculated $(\mathrm{t})$ indexed in the maanaweeh level (0.05)

The value of ( $\mathrm{R})$ in the timetable on Maanaweh standard $(0,05)=(0,27)$

It is shown that there is no relation between career pressure before and 25th January revolution and teaching Performance .The value of ( $R$ ) which is calculated less than the value of $(\mathrm{R})$ in the timetable on Moaanaweh standard $(50,5)$

There are relation between the career pressure after 25th revolution and the teaching Performance . The value of (R) which is calculated in higher than the value of $(R)$ in the timetable on Moaanaweh standard $(50,5)$

It is shown there is no relation between career pressures before25th January revolution and the teaching efficiency. this is due to losing financial and abstract appreciation to cope with exerted efforts and this can't satisfy daily need. Moreover there is no sufficient potentials in the schools for physical education. Some schools put the physical education lessons at the end of the school day although the physical education teacher is attended before the assembly.

the relation between the administration and the teacher may be bad.The relation between pupils and the teacher has a direct effect on the teacher performance.

these results agrees with Miller (2000) Harman, Anny and Don Gonarat ( 1999) Richardson study ( 1997) Noor Taha Ebrahim Hussein study
( 2008) Eman Hassan Elharony and Kawthar Abd Elhameed Elsaid study ( 2003) Mahmoud Mohamed kasm Allah study ( 2002) Ayman Ali Abd Elhameed Elshaer study ( 1999)

There are correlation relation between career pressures and teaching Performance after 25th January revolution. This is resulted from raising the spiritual of the teacher after the revolution and feeling of dignity. Moreover the feeling that what will come is better. They regain the feeling of loyalty to the homeland. All these factors encourage them to do well to raise their country. Before the revolution the didn't have these feelings because there were a lot of theft, big differences between the people. Thus the third supposition is achieved in a good percentage. these results agrees with Stuart Alai Buool Rich study(1999) Noor Taha Ebrahim Hussein study ( 2008) Eman Hassan Elharony and Kawthar Abd Elhameed Elsaid study ( 2003) Mahmoud Mohamed kasm Allah study ( 2002) Ayman Ali Abd Elhameed Elshaer study (1999)

\section{References}

1. Ahmed Mohamed Tayeb: Calendar and psychological and educational measurement, i 1, the modern university office and Alexandria, 1999.

2. Zahra Mohammed Rashad Hussain (1999): professional pressures and relation Achievement motivation among teachers of physical education preparatory and secondary levels, Master, unpublished, Minia University, Faculty of Physical Education, 1999.

3. Iman Hassan Alharony, and Kawthar Abd Majid Mr. (2003): The effect of the problems of physical education and school relationship competencies faculty of physical education teachers, Journal of Physical Education, Volume (3), number (60), the second part, Faculty of Physical Education for Boys, Zagazig University, 2003. 
4. Ayman Abdel-Hamid poet (1999 m): professional pressures for physical education teachers and relationship compatibility vocational, Master, unpublished, Zagazig University, College of Physical Education, 1999.

5. Khader Mkhaimar Zeid (2004 m): burnout among a sample of secondary education teachers and its relationship to some variables, scientific production, Assiut University, Journal of the Faculty of Education, Volume(12)Aaladd(2).

6. Shamma Mohammed Khalifa Al Khalifa $(1999 \mathrm{~m})$ : building a measure of psychological pressure and professionalism of teachers education Riadihvy second episode of basic education in Bahrain, Cairo, Ph.D. thesis, unpublished, Helwan University, Faculty of Physical Education for Boys, 1999.

7. Tariq Ismail Mahmoud (2002 m): stress education teachers at the stage of pre-university education in the province of Minya, unpublished Master, Faculty of Physical Education, Minia University,

2002.

8. Abdel Fattah Khleifat, Imad Zghoul (2003): Sources of stress in teachers D RSCN Terbahmhafezh and its relationship with some variables, Journal of Educational, AladeddaiJanuarypp.61-88Karak

9. Fathi Yusuf Mohammed (2003): Evaluating the performance efficiency of physical education teacher first stage of basic education in Alexandria, Ph.D. thesis, unpublished, Faculty of Physical Education for Boys, Alexandria University, 2002.

10. Mohamed Hassan Ahmed Marina: administrative pressure and its relationship to work efficiently with employees Directorate of Youth and Sports, Ph.D. thesis, unpublished, Helwan University, Faculty of Physical Education for Boys, 2006

11. Mohammed Hassan Mohammed Hamadat: Educational Leadership in the new century, Cairo Institute for Educational Studies and Research, 2006.

12. Mohamed Mohamed Abdo Aezzony: professional pressures and its relationship to behavior leading teaching and efficiency of Alterbahriadih teachers preparatory phase the governorates of Dakahlia, Damietta, Master, unpublished, Faculty of Physical Education, University of Mansoura, 2010,

13. Mustafa Al-Sayeh Mohammed, and Heba Abdel Azim Imbabi (2004): mastery of physical education teachers loop second basic education for efficiencies teaching (study polled senior teachers and mentors), Journal of the theories and applications, the number (51), Faculty of Physical Education in Abu Qir, Alexandria,2004.

14. Manal Jweideh Abu Glory (2005): A Study of professional pressures of physical education teachers in the light of the variables of sex, experience, age, Journal of the theories and applications, Faculty of Physical Education for Boys in Abu Qir Alexandria, No. 56.2005.

15. Nahed Ismail Mohammed (2005): Efficiency performance routers Physical Education for the preparatory phase, Ph.D. thesis, unpublished, Helwan University, College of EducationRiadihlbannat,2005.

16. Special Bulletin: Facts and the ministry's efforts in the past six months to improve the conditions of teachers and the educational process, September 2011

17. Noor Taha Ibrahim (2008): Performing calendar efficiency and structural relationship with the knowledge of teaching students in the Faculty of Physical Education, Mansoura University, unpublished Ph.D. Thesis, Faculty of Physical Education, Mansoura University, 2008.

18. Yourself Abdel Fattah Mohamed (1999 m): psychological stress among teachers and instructional needs, Journal of Educational Research Center, Qatar University, No. 15.1999.

19. Antonio ,M, j. ; :Francisco, S. A. ;Hereto ,R. ,uiz;rico ,A. ; Antonia ,Y(2005):analys y comparacion delnivelde burnout en des professions asistenciales/analysis and comparison of burnout in two welfare professions .(Spain: university of Cordoba).

20. Don Jonarat :Analysis of the Dialogue to Understand the Pressures Teachers, 1999.

21. Richardson Arthur G:Strees in teaching :astudy of Elementary school teachers in coribbean, record 10 of 23 the ERIC Database ,1997. 
22. Kidzui :Student Awareness of the Efficiency of Physical Education Teacher for Children Ages (7-11) Years in the United Kingdom, the United Kingdom, Faculty of Physical Education, 2000 .

23. Kokkinos,constantions. M. (2006):"Factor structure and psychometric properties of the masisch and inventory "Journal of The International Society for The Investigation of stress, vol .No. I, Bef. Pp25-33.

24. Miller :Efficiency Performance of Professional Preparation for Teachers of the Twenty-First Century, America 2000.
25. Susanne Carter)1994(:Teacher Stress and Burnout, Organizing system to Support Competent Social Behavior in Children and Youth, record 123 of 150-the ERIC Database.

26. Harman and Annie :Evaluating Teaching Performance with the Scientific Level, U.S.A, 2000.

27. Haser S.G .\&Nasser I. (2002):Teacher Job Satisfaction in a Year Round School ,Educational Leadership ,V(60), N(2).

28. Stuart Ely and Puyol Rich :Factors Affecting the Performance of Teacher, America 1999 